ISSN 0258-7122

Bangladesh J. Agril. Res. 40(3): 435-450, September 2015

\title{
VARIABILITY AND HERITABILITY ANALYSIS IN SPRING WHEAT (Triricum aestivum L.) GENOTYPES
}

\author{
M.F. AMIN ${ }^{1}$, M. HASAN $^{2}$, N. C. D. BARMA ${ }^{3}$ \\ M. M. RAHMAN ${ }^{4}$ AND M. M. HASAN ${ }^{5}$
}

\begin{abstract}
The experiment was carried out with 50 wheat lines to study their intergenotypic variability, heritability, GCV, PCV, genetic advance, and $\mathrm{CV}$ percent considering 14 morphological characters at the experimental field of Regional Wheat Research Centre RWRC), Bangladesh Agricultural Research Institute (BARI), Gazipur during November 2010 to March 2010. Significant variation was observed among the genotypes for all characters studied. High GCV and PCV values were observed for grain filling duration, grain filling rate, and seed yield. High heritability along with higher genetic advance was observed for

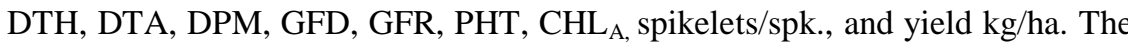
remaining traits showed lower heritability coupled with low genetic advance in percent of mean. Considering variability among the genotypes, heritability, genetic advance, percent co-efficient of variation, and field performances, the genotypes G 3, G 10, G 11, G 12, G13, G 21, G 29, G 35, G 38, G 40, G 46 and $\mathrm{G} 48$ were found suitable for future breeding programme.
\end{abstract}

Keywords: Wheat, Genotypes, Variability, Heritability .

\section{Introduction}

Wheat is the most widely grown and consumed food crop in the world (Vasil and Anderson, 1997). Intensive breeding in modern times has led to the adaption of wheat to a wide range of ecological conditions (temperate, subtropical, and tropical). Even in Asia, where rice has historically been the dominant crop, wheat is fast becoming a major crop. For example, in 1994, Asia produced 217 million tons of wheat compared with a combined harvest of 209 million tons in USA, Canada, Europe and Mexico (Vasil and Anderson, 1997). In addition to wheat being grown in countries not traditionally associated with wheat growing, over the past 40 years the introduction of new cultivars and improved husbandry has led to major increase in global wheat yield (2\% increase annually from 19611994) (Braun et al., 1998). Wheat Research Centre (WRC) of Bangladesh Agricultural Research Institute (BARI) now has a wide range of spring wheat germplasm collection from different sources. Most of these have been collected

\footnotetext{
${ }^{1 \& 5}$ Scientific Officer, ${ }^{4}$ Senior Scientific Officer, and ${ }^{3}$ Chief Scientific Officer, Regional Wheat Research Centre (RWRC), Bangladesh Agricultural Research Institute (BARI), Gazipur, ${ }^{2}$ Associate Professor, Department of Genetics and Plant Breeding, Bangabandhu Sheikh Mujibur Rahman Agricultural University (BSMRAU), Salna, Gazipur, Bangladesh.
} 
from International Maize and Wheat Improvement Centre (CIMMYT), Mexico and few from Nepal, India, Pakistan, and Australia.

Now, there is a need for improved varieties in respect of heat, drought and disease tolerance and germplasm is the important natural resource that should be used by the breeders to develop new cultivars. Genetic variability is a prerequisite for a successful breeding programme of any crop species and a critical survey of genetic variability is essential before initiating an improvement programme aiming to develop high yielding varieties (Falconer, 1989).The variability analysis and partitioning of the total variation into heritable and nonheritable components with suitable genetic parameters like genotypic coefficient of variation (GCV), phenotypic coefficient of variation (PCV), percent heritability, percent genetic advance etc. is therefore, a necessity (Barma et al., 1990). The genetic variability in a population along with heritability gives an idea of genetic advance to be expected from selection for a given character (Burton, 1952; Johanson et al., 1955). The present, attempts have been made to characterize a set of wheat germplasm for various morphological characters and estimate the variabilities available in the collections, which can be utilized as donors in hybridization programme.

\section{Materials and Method}

Fifty wheat genotypes were grown in a randomized complete block design with three replications at the experimental field of Bangladesh Agricultural Research Institute, Gazipur during first week of December 2010 to first week of April 2011. The experimental site was at $23.46^{\circ} \mathrm{N}$ latitude and $90.23^{\circ} \mathrm{E}$ longitude with an elevation of 8 meter from sea level. The experimental field was prepared thoroughly by ploughing with tractor followed by harrowing and removing the stubble. The crop was fertilized with NPKS and B @ 100, 28, 40, 20 and $2.5 \mathrm{~kg}$ $\mathrm{ha}^{-1}$, respectively to ensure proper growth and development of wheat plant. The elements N, P, K, S and B were applied in the form of Urea, Triple Super Phosphate, Muriat of Potash, Gypsum and Boric acid, respectively. Two-third of urea and the entire quantity of other fertilizers were applied at final land preparation along with Furadon 3G @ $8 \mathrm{~kg} \mathrm{ha}^{-1}$. The rest one-third urea was topdressed at crown root initiation stage (17-21 days after sowing) following first irrigation. Data were collected on days to heading (DTH), days to anthesis (DTA), days to maturity (DTM), grain filling duration (GFD)[days], grain filling rate (GFR) $\left[\mathrm{g} \mathrm{m}^{-2} \mathrm{~d}^{-1}\right]$, plant height (PHT) in $\mathrm{cm}$, chlorophyll content at anthesis $\left(\mathrm{CHL}_{\mathrm{A}}\right)$ in SPAD unit, canopy temperature $\left({ }^{0} \mathrm{C}\right)$ at vegetative $\left(\mathrm{CT}_{\text {veg. }}\right)$, anthesis $\left(\mathrm{CT}_{\text {anth. }}\right)$ and grain filling $\left(\mathrm{CT}_{\text {gf. }}\right)$ stage, spikelets spike ${ }^{-1}$ (no.), grains spike ${ }^{-1}$ (no.), thousand grain weight (TGW) $[\mathrm{g}]$, and grain yield $\mathrm{m}^{-2}(\mathrm{~g})$. Grain yield $\mathrm{m}^{-2}$ of each genotype was converted into grain yield $(\mathrm{Kg} / \mathrm{ha})$. The data were analyzed for phenotypic and genotypic variances (Johnson et al., 1955). The Genotypic and 
phenotypic coefficients of variations were estimated according to the formula suggested by Burton (1952). Heritability in broad sense $\left(h^{2} b\right)$, genetic advance (GA), and genetic advance in percent of mean (GA\%) were estimated for different characters by the formula suggested by Johnson et al., (1955) and Hanson et al., (1956), Allard (1960) and Comstock and Robinson (1952), respectively.

\section{Results and discussion}

The mean, range, and CV of seed yield and yield contributing characters of 50 genotypes of spring wheat (Triticum aestivum L.) are presented in Table 1. Variations were observed among the lines for all the characters studied. The average days to heading (DTH) across genotypes was 72.77 days and ranged from 61 to 79. The minimum DTH was observed in genotype G 21 (61.67 days) and the maximum (79 days) in genotype G 27 (Table 2). Days to anthesis (DTA) ranged from 65 to 84 . The shortest vegetative period was observed in the genotype G 21 (65.33) and the longest (84.33) in the genotype G 27 (Table 2). Days to physiological maturity (DPM) ranged from 98 to 111. The lowest days to physiological maturity was observed in the genotype G 21 (98.33) and the highest (111.33) in the genotype G 27 (Table 2). Grain filling duration (GFD) ranged from 23 to 34 . The shortest GFD was recorded in genotype G 29 (23.33 days) and the longest one (34.00 days) in genotype $\mathrm{G} 44$ (Table 2). The average Grain filling rate (GFR) across genotypes was $14.43 \mathrm{~g} \mathrm{~g}^{-2} \mathrm{~d}^{-1} \mathrm{~m}^{-2}$ and ranged from 10.07 to 18.98 . Minimum GFR was observed in genotype $\mathrm{G} 3\left(10.07 \mathrm{~g}^{-2} \mathrm{~d}^{-1} \mathrm{~m}^{-2}\right)$ and the maximum $\left(18.98 \mathrm{~g}^{-2} \mathrm{~d}^{-1} \mathrm{~m}^{-2}\right)$ in genotype $\mathrm{G} 40$ (Table 2). Plant height (PHT) ranged from 80 to $98 \mathrm{~cm}$. The minimum plant height was observed in the genotypes $\mathrm{G} 3(80.33 \mathrm{~cm})$ and the maximum $(97.67 \mathrm{~cm})$ in the genotype $\mathrm{G} 4$ and G16 (Table 2). The average Chlorophyll content at anthesis stage $\left(\mathrm{CHL}_{\mathrm{A}}\right)$ across genotypes was 49.51 SPAD unit for all genotypes and ranged from 43.50 to 54.53. Highest chlorophyll content (54.50 SPAD unit) was recorded in genotype G 45 while the lowest chlorophyll content (43.50 SPAD unit) was recorded in G 2 (Table 2). The canopy temperature measured by infrared thermometer has been used to evaluate genotypes for their ability to keep their canopy cool with less impaired assimilation processes as suggested by Reynolds et al., (1994). Canopy temperature at vegetative stage $\left(\mathrm{CT}_{\text {veg. }}\right)$ ranged from 19.90 to $22.50^{\circ} \mathrm{C}$. Minimum average canopy temperature at vegetative stage was recorded in the genotype $\mathrm{G} 46\left(19.90{ }^{\circ} \mathrm{C}\right)$ and the maximum $\left(22.50{ }^{\circ} \mathrm{C}\right)$ was in the genotype $\mathrm{G} 7$ (Table 2). Canopy temperature at anthesis stage $\left(\mathrm{CT}_{\text {anth. }}\right.$ ranged from 21.10 to $23.50^{\circ} \mathrm{C}$. Minimum average canopy temperature was recorded in the genotype G 39 $\left(21.10{ }^{\circ} \mathrm{C}\right)$ and the maximum $\left(23.50{ }^{\circ} \mathrm{C}\right)$ was in the genotype $\mathrm{G} 15$ (Table 2). Canopy temperature at grain filling stage $\left(\mathrm{CT}_{\text {gf. }}\right)$ ranged from 21.50 to $24.90^{\circ} \mathrm{C}$. 
The minimum average canopy temperature was recorded in the genotype $\mathrm{G} 44$ $\left(21.50{ }^{\circ} \mathrm{C}\right)$ and the maximum $\left(24.90{ }^{\circ} \mathrm{C}\right)$ was in the genotype $\mathrm{G} 15$ (Table 2). Spikelets spike $^{-1}$ (Splet/spk.) ranged from 13.90 to 18.40 . The minimum spikelets spike $^{-1}$ was produced by the genotype G 3 (13.90) and the maximum (18.40) by genotype $\mathrm{G} 38$ (Table 2). The average Grain spike ${ }^{-1}$ across genotypes was 50.74 and ranged from 40.70 to 57.90 . Genotype $\mathrm{G} 49$ produced minimum grains spike ${ }^{1}$ (40.70) while G 35 produced the maximum (57.90) grains spike ${ }^{-1}$ (Table 2). Thousand grain weight (TGW) ranged from $30.50 \mathrm{~g}$ to $45.90 \mathrm{~g}$. The lowest $1000-$ grain weight was recorded in the genotype $\mathrm{G} 4(30.50 \mathrm{~g})$ and the highest $(45.90 \mathrm{~g})$ was in genotype G 13 (Table 2). The average Grain yield was $3810.14 \mathrm{~kg} \mathrm{ha}^{-1}$ for all genotypes and ranged from 2552 to 4998 . G 41 was the lowest yielder $\left(2552.00 \mathrm{~kg} \mathrm{ha}^{-1}\right)$ while $\mathrm{G} 40$ was the highest yielder (4998.00 $\left.\mathrm{kg} \mathrm{ha}^{-1}\right)$ among the genotypes studied (Table 2). The hieghest co-efficient of variation (CV\%) was recorded in the character grain filling rate (8.7) followed by grain yield (8.54), grains spike $^{-1}$ (7.60), and TGW (7.07).

Minimum variation was observed in the character days to anthsis (1) [Table 1]. The coefficient of variation (CV \%) was not so high and ranged from 1 to 8.7, which indicated that the reliability level of results for these traits was high. Considering plant height, days to heading, days to maturity, grain filling duration, grain spike ${ }^{-1}$, spikelets spike ${ }^{-1}$, thousand grain weight, seed yield and other yield contributing characters, the genotypes G 3, G 13, G 21, G 29, G 35, G 38 , G40, and G 46 were selected for future breeding programme.

\section{Variability among the genotypes}

Out of 50 wheat genotypes the lowest days to heading was taken by genotype G21 (61.77 days) followed by genotype G8 (62.33 days), G44(62.67 days), and G1 (66.33 days). The highest days to heading was taken by genotype G 27 (79.00), which was close to genotype G32 (77.33 days) [Table 2]. The low and close GCV (5.09) and PCV (5.20) indicated narrow range of genotypic variability along with less influence of environment for the expression of this trait. Barma et al., (1990) and Rahman (2009) reported a narrow range of variation among genotypes for this trait (Table 3).

The highest days to anthesis was observed in genotype G27 (84.33 days) followed by G 25 (82.67 days) and G29 (81.67 days), whereas the lowest days to anthesis was observed in genotype G21 (65.33 days) [Table 2]. The phenotypic coefficient of variation (5.40) and genotypic coefficient of variation (5.30) were low and close to each other. This is indicating less influence of environment for the expression of this trait and at the same time narrow range of genetic variation among genotypes for DTA (Table 3). 


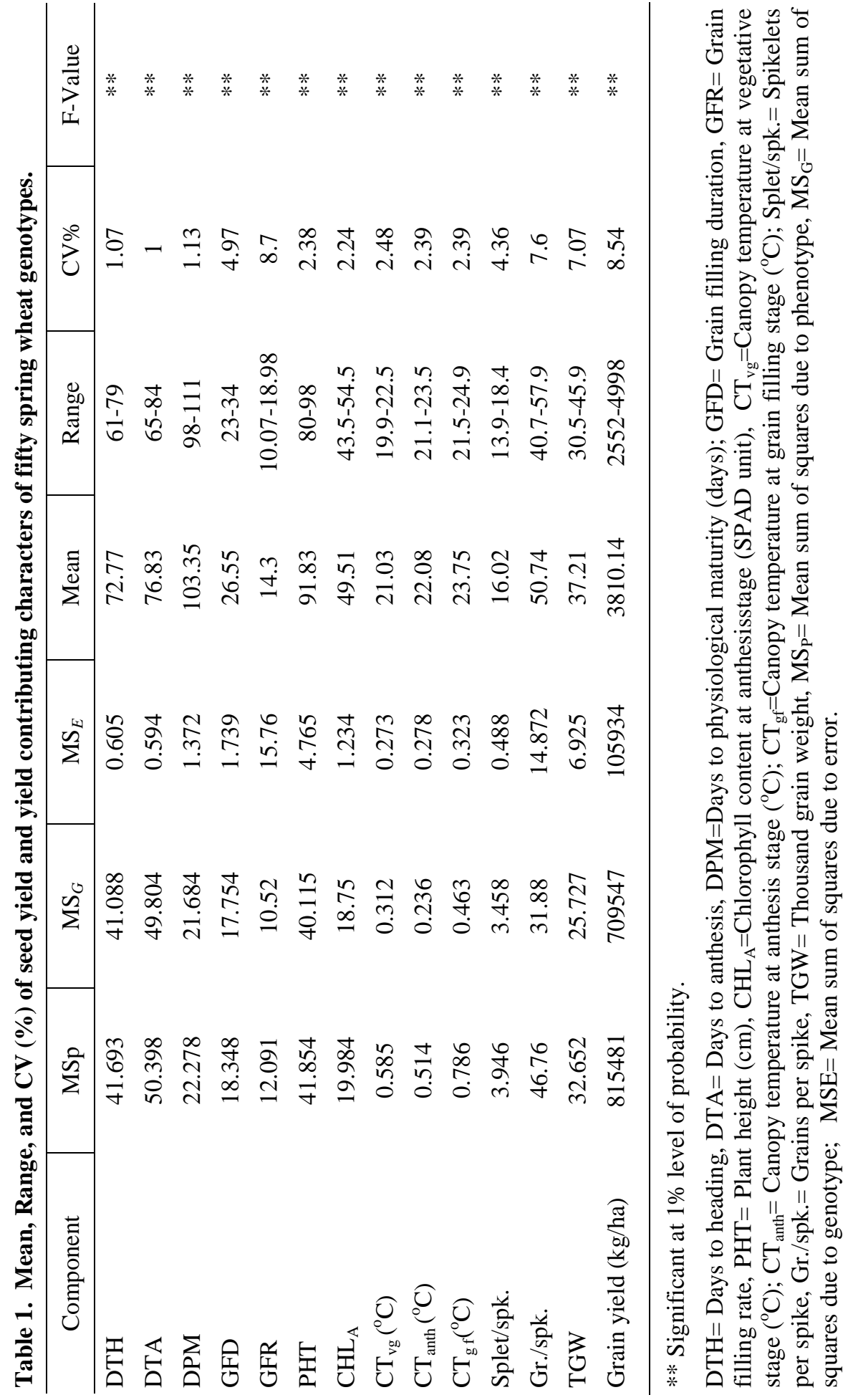


Among 50 genotypes, the highest days to physiological maturity was observed in genotype G 27 (111.33 days), whereas the lowest was in genotype G21 (98.33 days) followed by G40 (99.67 days) and G 8 (99.67 days) [Table 2]. The phenotypic coefficient of variation (2.79) and genotypic coefficient of variation (2.60) were low and close to each other indicating narrow range of genetic variation and at the same time very small environmental influence for the expression of this trait (Table 3 ).

The highest grain filling duration was observed in genotype G44 (34.00 days) followed by G8 (33.67 days) and G21 (33.00 days), whereas the lowest was observed in genotype G29 (23.33 days), which was close to genotype G50 (23.67), G49 (23.67 days), and G41(23.67 days) [Table 2]. The phenotypic coefficient of variation (10.16) was close to genotypic coefficient of variation (9.16) (Table 1). So, environment had a minor influence for the expression of this trait (Table 3).

The highest grain filling rate was observed in genotype G40 (18.98 $\left.1 \mathrm{~g} \mathrm{~g}^{-2} \mathrm{~d}^{-1} \mathrm{~m}^{-2}\right)$ followed by G48 (18.15 $\left.1 \mathrm{~g} \mathrm{~g}^{-2} \mathrm{~d}^{-1} \mathrm{~m}^{-2}\right)$ and $\mathrm{G} 11\left(17.651 \mathrm{~g}^{-2} \mathrm{~d}^{-1} \mathrm{~m}^{-2}\right)$, whereas the lowest was observed in genotype G3 $\left(10.07 \mathrm{~g}^{-2} \mathrm{~d}^{-1} \mathrm{~m}^{-2}\right)$ followed by genotype G41 (10.78 $1 \mathrm{~g} \mathrm{~g}^{-2} \mathrm{~d}^{-1} \mathrm{~m}^{-2}$ ) and G5 (10.99 $1 \mathrm{~g} \mathrm{~g}^{-2} \mathrm{~d}^{-1} \mathrm{~m}^{-2}$ ) [Table 2]. The phenotypic coefficient of variation (15.63) and genotypic coefficient of variation (12.98) was moderate. Little difference in phenotypic and genotypic coefficient of variation indicated less influence of environment for the character (Table 3).

The highest plant height was observed in genotype G4 (97.67 cm), G16 (97.67 $\mathrm{cm})$, and G30 $(97.67 \mathrm{~cm})$, whereas the lowest plant height was observed in genotype G3 $(80.33 \mathrm{~cm})$ followed by the genotypes $\mathrm{G} 41(81.33 \mathrm{~cm})$ and $\mathrm{G} 21(83$ $\mathrm{cm}$ ) [Table 2]. Lower estimate of phenotypic coefficient of variation (4.51) was little higher than genotypic coefficient of variation (3.98) indicating narrow range of genetic variation as well as some degree of environmental influence for the expression of this trait (Table 3).

The highest chlorophyll content at anthesis stage was observed in genotype G45 (54.53 SPAD unit) followed by genotype G 12 (53.67 SPAD unit) and G9 (53.63 SPAD unit), whereas the lowest was observed in genotype G2 (43.47 SPAD unit) [Table 2]. Lower estimate of phenotypic coefficient of variation (5.53) was slightly higher to genotypic coefficient of variation (5.05) indicating narrow range of genetic variation as well as some degree of environmental influence for the expression of this trait (Table 2).

The highest canopy temperature at vegetative stage was found in genotype G7 (22.47) and the lowest was in genotype G46 (19.93) [Table 2]. The PCV (2.92) 
was higher to GCV (1.53), indicating that the environment itself had played major role for the expression of this trait (Table 3).

The highest canopy temperature at anthesis stage was found in genotype G15 (23.47) and the lowest was found in genotype G39 (21.17) [Table 2]. The PCV (2.70) was higher to GCV (1.27), indicating that the environment itself had played major role for the expression of this trait (Table 3).

The highest canopy temperature at grain filling stage was found in the genotype G15 (24.97) and the lowest was in genotype G44 (21.50) [Table 2]. The phenotypic coefficient of variation (2.91) was higher to genotypic coefficient of variation (1.65), indicating the presence of environmental influence for the expression of this trait (Table 3 ).

The highest number of spikelets spike ${ }^{-1}$ was produced by the genotype G38 (18.37) which was followed by the genotypes G42 (18.10) and G 5(17.60) [Table 2]. The phenotypic coefficient of variation (7.99) was little higher to genotypic coefficient of variation (6.70) [Table 3]. So, it could be realized that range of genetic variation for the expression of this trait was narrow and environment might have very minor influence.

The highest number of grains spike ${ }^{-1}$ was found from the genotype G35 (57.93) followed by the genotypes G25 (56.90) and G30 (56.77), whereas the lowest grains spike ${ }^{-1}$ was produced by the genotype G49 (40.73) [Table 2]. The phenotypic coefficient of variation (9.95) was higher to genotypic coefficient of variation (6.42) indicating a considerable level of environmental influence for the expression of this trait (Table 3).

The highest thousand grain weight (TGW) was observed in genotype G13 (45.90 g.) followed by that of the genotypes G40 (42.40g.) and G 17 (42.20 g.), whereas the lowest was observed in genotype G4 (30.50 g.) [Table 2]. The phenotypic coefficient of variation (10.58) was higher to genotypic coefficient of variation (7.87) indicating a considerable level of environmental influence for the expression of this trait (Table 3). Chaturvedi and Gupta (1995) found phenotypic variation being higher than the genotypic variation.

In this experiment, the highest variation was found for grain yield. The highest grain yield was produced by the genotype G40 (4998 kg/ha.) followed by the genotypes G11 (4905 kg/ha.) and G12 (4899 kg/ha.), whereas the lowest grain yield was produced by the genotype G41 (2552 kg/ha.) [Table 2]. The phenotypic coefficient of variation (15.36) was higher to genotypic coefficient of variation (12.76) indicating a considerable level of environmental influence for the expression of this trait (Table 3). 
The analysis of variance showed significance differences among the genotypes for all the characters. The ranges were high for most of the traits also. In order to obtain a clear understanding of the pattern of variations, the phenotypic variances were portioned into genotypic and environmental variances. The highest genotypic, environmental, and phenotypic variances were found in grain yield. The lowest variances were found in canopy temperature at anthesis stage. The phenotypic co-efficient of variations (PCV) were higher than the genotypic coefficient of variations (GCV) for all the characters studied indicating the presence of environmental influence in the phenotypic expression of the characters. The difference between PCV and GCV was remarkably low for days to anthesis. The difference between PCV and GCV was high for grains spike ${ }^{-1}$.

\section{Heritability and genetic advance}

The knowledge of heritability of a character helps the breeder in predicting the behavior of the succeeding generation and making desirable selections. Days to heading exhibited higher estimate of broad sense heritability (95.8\%) along with low genetic advance in percent of mean (8.76\%) suggests that improvement through phenotypic selection for this trait is feasible but it may not be rewarding (Table 3).

Days to anthesis showed higher estimate of broad sense heritability (96.5\%) and low genetic advance in percent of mean (9.17) [Table 3]. Rahman (2009) observed similar results in spring wheat. Direct phenotypic selection may lead to some limited improvement in this trait but it may not be rewarding.

Days to physiological maturity (DPM) showed very high estimate of broad sense heritability (83.6\%) and the genetic advance in percent of mean (4.11) was low (Table 3). All these indicated that the trait might be governed by non-additive gene action; hence there is few to zero probability of getting positive response through selection.

Grain filling duration exhibited higher estimate of broad sense heritability (76.10) along with moderate genetic advance in percent of mean (13.60) assuming that phenotypic selection may provide some improvement for this trait as there might be presence of additive gene action (Table 3 ).

Grain filling rate exhibited higher estimate of broad sense heritability (87.00) coupled with higher genetic advance in percent of mean (23.93) [Table 3]. Direct phenotypic selection will result in good positive improvement of this trait as there might be presence of additive gene action which had the late heat stress tolerance mechanism. Barma (2005) reported high heritability coupled with moderate genetic advance for this trait. 
Plant height showed higher estimate of broad sense heritability (72.2) and lower genetic advance in percent of mean (5.73) [Table 3]. Under such indications selection for this character will not be effective. Ali et al., (2008) and Rahman (2009) reported moderate heritability along with low genetic advance in spring wheat for plant height

Chlorophyll content at anthesis stage showed higher estimate of broad sense heritability $(83.5 \%)$ along with lower genetic advance in percent of mean (8.12), which indicated that both additive and non-additive gene action was present there (Table 3). Direct phenotypic selection has limited chance for the improvement of this trait. Barma (2005) reported moderately high broad sense heritability coupled with moderate genetic advance in percent of mean for chlorophyll content.

Canopy temperature at vegetative stage exhibited lower estimate of broad sense heritability (27.6\%) along with lower genetic advance in percent of mean (1.42) again reveals preponderance of non-additive gene action (Table 3). Raynolds et al, (1997) reported sensitivity of canopy temperature to environmental fluxes along with moderate heritability. Selection for this character will not be effective.

Canopy temperature at anthesis stage exhibited lower estimate of broad sense heritability $(22.1 \%)$ along with lower genetic advance in percent of mean (1.05) again reveals preponderance of non-additive gene action (Table 3). Reynolds et al., (1997) reported that canopy temperature is quite sensitive to environmental fluxes and moderate heritability values were found for this trait. Selection for this character will not be effective.

Canopy temperature at grain filling stage showed moderate estimate of broad sense heritability (32.3\%) along with lower genetic advance in percent of mean (1.66) suggests that there were predominance of non-additive gene action (Table 3). Rahman (2009) observed lower genetic advance along with moderate heritability for canopy temperature in spring wheat. Selection for these traits will not be effective.

Spikelets spike ${ }^{-1}$ exhibited higher estimate of broad sense heritability (70.3) but lower genetic advance in percent of mean (9.88) [Table 3]. Phenotypic selection may provide some improvement for this trait as there might be presence of nonadditive gene action. Ali et al., (2008) estimated high heritability coupled with high genetic advance for spikelets spike ${ }^{-1}$.

Grains spike ${ }^{-1}$ exhibited moderate estimate of broad sense heritability $(41.7 \%)$ along with lower genetic advance (7.30) in percent of mean suggests that there were predominance of non-additive gene action (Table 3). Direct phenotypic selection has limited chance for the improvement of this trait. Sharma et al., (1995) reported high genotypic coefficient of variation, high heritability and high genetic advance in grains spike ${ }^{-1}$, suggesting the operation of additive gene effect for these traits 


\begin{tabular}{|c|c|}
\hline 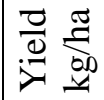 & 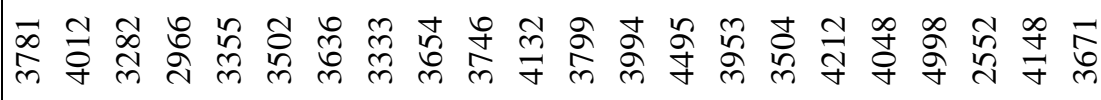 \\
\hline 勇 & 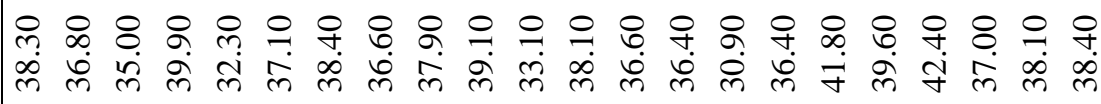 \\
\hline$\frac{\dot{v}}{\dot{n}}$ & 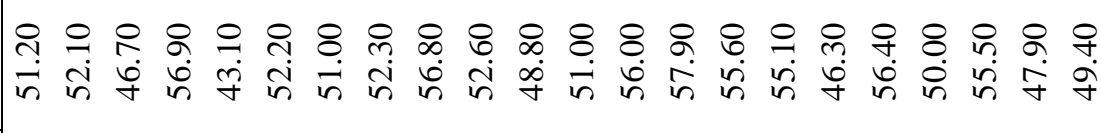 \\
\hline $\begin{array}{l}\frac{\dot{a}}{2} \\
\frac{0}{2} \\
\frac{\overrightarrow{0}}{2} \\
\frac{2}{2}\end{array}$ & 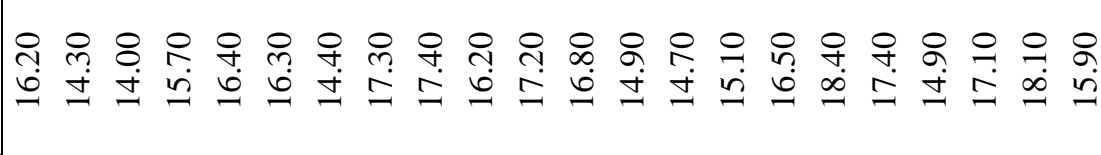 \\
\hline$\vartheta^{+\infty} \circlearrowright$ & 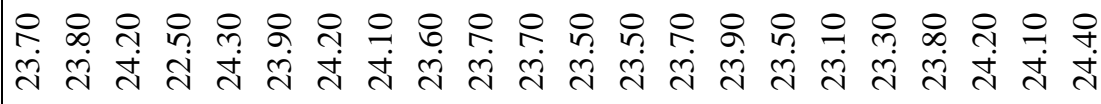 \\
\hline 童 & 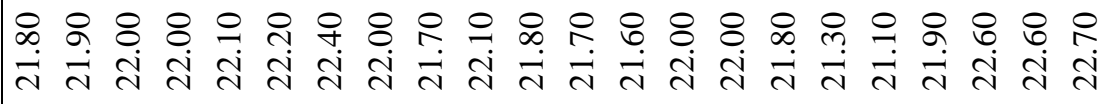 \\
\hline$\overbrace{}^{\infty 00} 0$ & 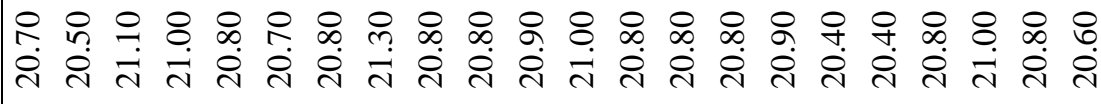 \\
\hline 芭 & 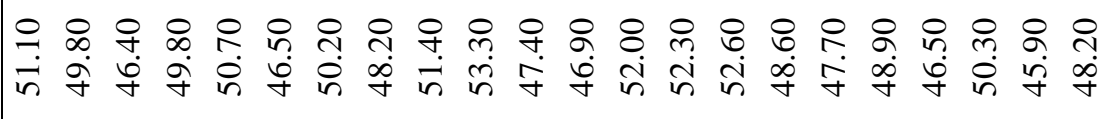 \\
\hline 焉 & 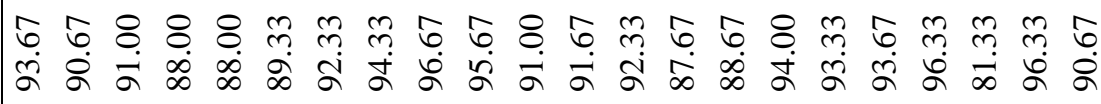 \\
\hline$\frac{0}{0}$ & 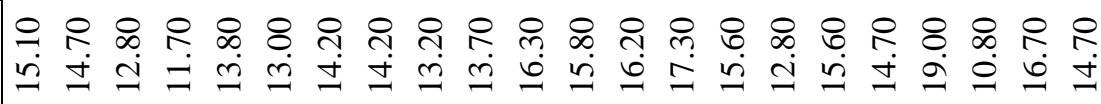 \\
\hline 空 & 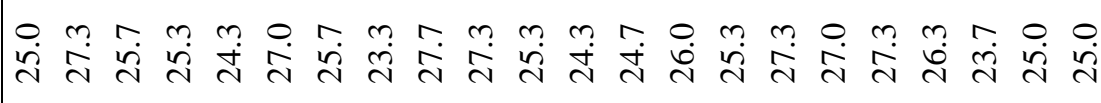 \\
\hline 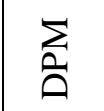 & 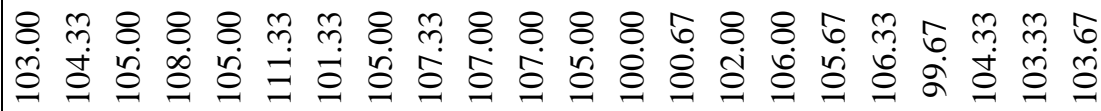 \\
\hline 岕 & 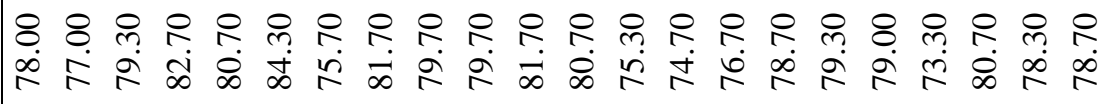 \\
\hline 晃 & 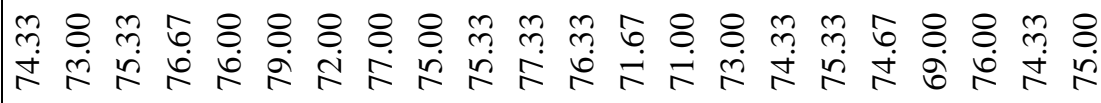 \\
\hline 气 & $\approx$ \\
\hline
\end{tabular}




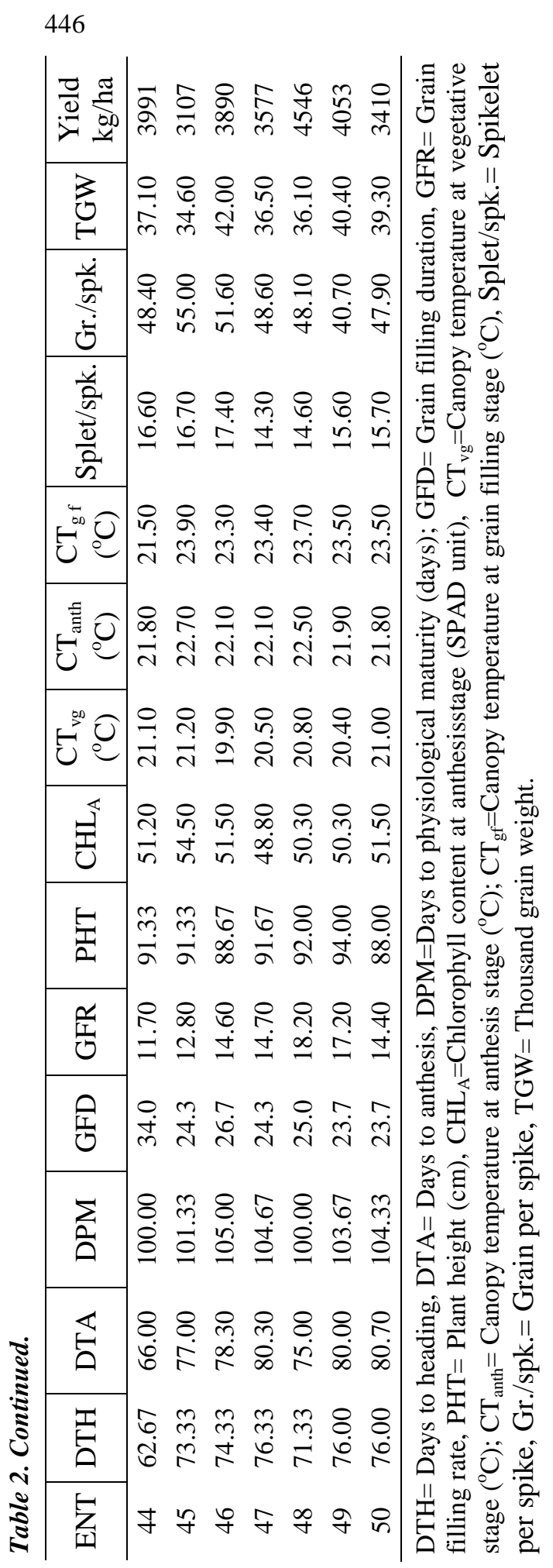

AMIN et al. 
Thousand grain weight exhibited higher estimate of broad sense heritability (55.3\%) along with lower genetic advance in percent of mean (10.30) [Table 3]. Phenotypic selection may provide some improvement for this trait as there might be presence of non-additive gene action. Chaturvedi and Gupta (1995) found higher estimates of heritability for 1000-grain weight. Many other authors reported high heritability along with high genetic advance for 1000-grain weight (Sharma et al., 1995; Shoran, 1995; Vilhelmsen et al., 2001 and Ali et al., 2008).

Grain yield showed high estimate of broad sense heritability $(69.10 \%)$ along with moderate genetic advance in percent of mean (18.67) indicating the presence of additive and non-additive gene action for the expression of this trait [Table 3]. There is a scope of phenotypic selection for the improvement of this trait. Many authors found high heritability along with high to moderate genetic advance for grain yield in wheat (Barma, 2005; Singh et al., 2006; Ali et al., 2008; Rahman, 2009).

Genotypic co-efficient of variation together with high heritability and genetic advance are considered as good estimates of genetic gain to be expected in making selection of superior genotypes on the basis of phenotypic performance. Johnson et al., (1955) mentioned that high heritability along with high genetic gain are more successful than the heritability alone to select desirable genotypes with higher yield.Panse (1957) stated that high value of heritability with low genetic advance indicated that the heritability was probably due to the effect of non-additive gene action. The characters with high values of GCV, PCV, and heritability accompanied by high genetic advance in percent of mean might be transmitted to their progenies and therefore, phenotypic selection based on these characters would be effective.

Estimated phenotypic coefficient of variation (PCV) and genotypic coefficient of variation $(\mathrm{GCV})$ revealed higher to moderate range of genetic variations for most of the phenological and physiological traits. Grain filling period, grain filling rate, grain yield, exhibited more than $10 \% \mathrm{GCV}$. DTH, DTA, $\mathrm{CHL}_{\mathrm{A}}$, spikelets spike $^{-1}$, grains spike ${ }^{-1}$, TGW also had moderate range of $\mathrm{PCV} \%$ and GCV\%. DPM, PHT, $\mathrm{CT}_{\text {vg }}\left({ }^{\circ} \mathrm{C}\right), \mathrm{CT}_{\mathrm{g}}\left({ }^{\circ} \mathrm{C}\right), \mathrm{CT}_{\text {anth }}\left({ }^{\circ} \mathrm{C}\right)$, had lower GCV estimate $(<10 \%)$ indicating narrow range of genetic variation. The PCV and corresponding GCV estimates were close to each other for $\mathrm{CHL}_{\mathrm{A}}$, DTA, DPM, DTH indicating less influence of environment for the expression of these traits. On the other hand the PCV estimate for GFD, GFR, PHT, $\mathrm{CT}_{\mathrm{vg}}\left({ }^{\circ} \mathrm{C}\right), \mathrm{CT}_{\text {anth }}\left({ }^{\circ} \mathrm{C}\right), \mathrm{CT}_{\mathrm{g}}\left({ }^{\circ} \mathrm{C}\right)$, spikelets spike $^{-1}$, grains spike ${ }^{-1}, \mathrm{TGW}$, and yield $(\mathrm{kg} / \mathrm{ha})$, were moderately higher to much higher than corresponding GCV indicating that the environment had moderate to major influence for the expression of these traits. 


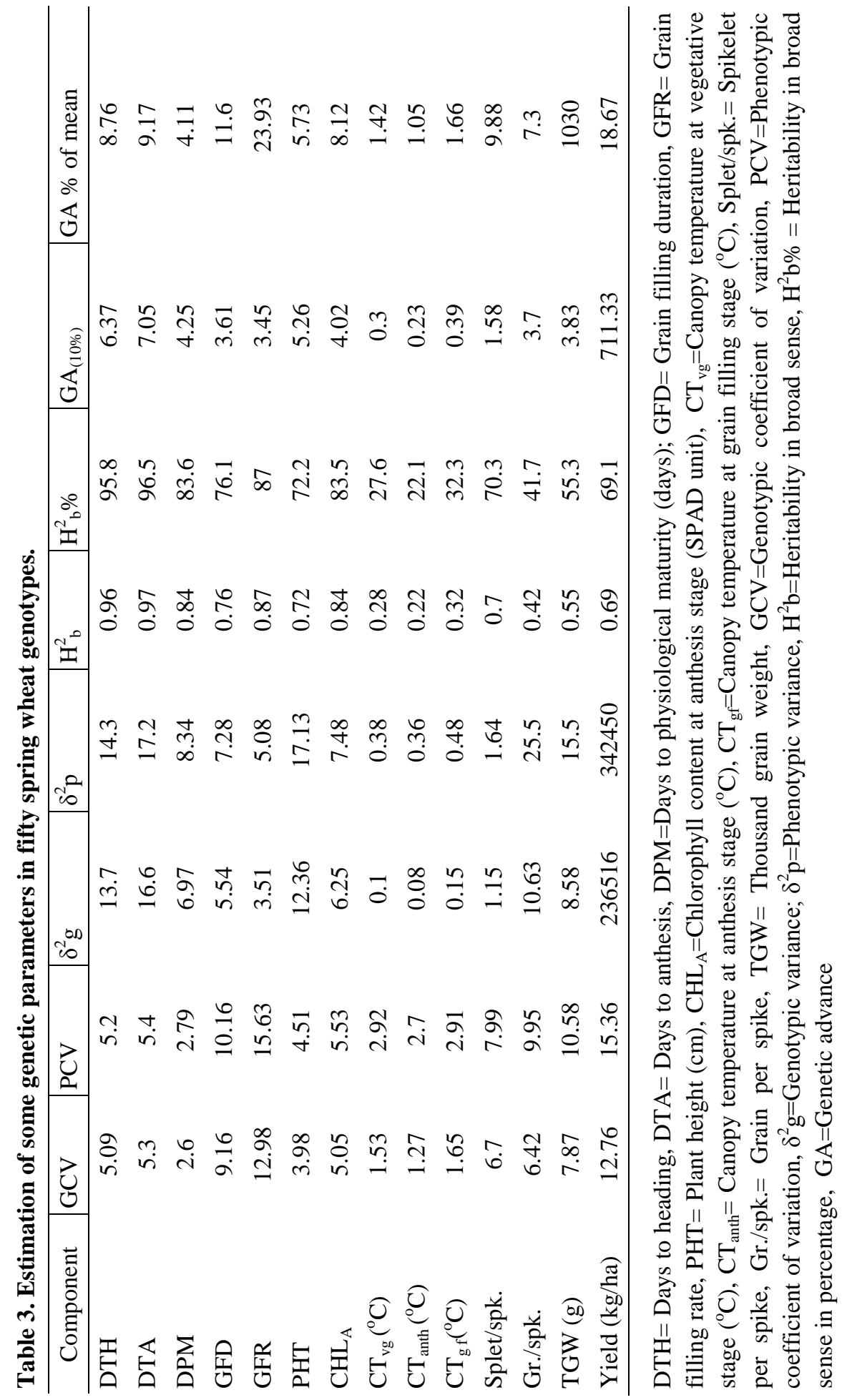


High heritability along with higher genetic advance was observed for DTH, DTA, DPM, GFD, GFR, PHT, $\mathrm{CHL}_{\mathrm{A}}$, spikelets spike ${ }^{-1}$, and yield (kg/ha) indicated that direct phenotypic selection has good chances to bring some good improvement in these traits. The remaining traits showed lower heritability coupled with low genetic advance in percent of mean indicating that selection has little to no chance for improvement. Considering variability among the genotypes, heritability, genetic advance, percent co-efficient of variance, and field performances, the genotypes G 3, G 10, G 11, G 12, G13, G 21, G 29, G 35, $\mathrm{G} \mathrm{38,} \mathrm{G} \mathrm{40,} \mathrm{and} \mathrm{G} 48$ were found suitable for future breeding programme.

\section{References}

Allard, R. W. 1960. Principles of Plant Breeding. John Wiley and Sons. Inc. New York.

Ali, Y., B. Manzoor, J. Akhter, P. Monneveux and Z. Lateef. 2008. Genetic Variability, Character Association and Diversity Studies in Wheat. Pak. J. Bot. 40(5): 20872097.

Barma, N.C.D. 2005. Genetic study of morpho-physiological traits related to heat tolerance in spring wheat. Ph.D. Thesis, Dept. of Genetics and Plant Breeding, BAU, Mymensingh.

Barma, N. C. D., S. H. Khan, M. A. K. Mian and A. Islam. 1990. Variability and Interrelationships of eight Quantitative Characters in Bread Wheat (Triticum aestivum L.). Bangladesh J. Plant Breed. Genet. 3(1 \& 2): 71-75.

Braun, H.J., T.S.Payne, A.I. Morgounov, M. van Ginkel, and S. Rajaram, (1998).The challenge: one billion tons of wheat by 2020. In: AE. Slinkard (ed.), Proceedings of the 9th International Wheat Genetics Symposium, Saskatoon, Canada, vol I, Pp. 33-40.

Burton, G. W. 1952. Quantitative inheritance in grasses. Proc. sixth Int. Grassland Cong. 1: 277-283.

Comstock, R.E. and H.F. Robinson. 1952. Genetic parameters, their estimation and significance. Proc. sixth Int. Grassland Cong. 1: 284-291.

Chaturvedi, B. K. and R. R. Gupta. 1995. Selection parameters for some grain and quality attributes in spring wheat (Triticum aestivum L.). Agric. Sci. Digest. 15(4): 186-190, Karnal, India.

Falconar, D. S. 1989. Introduction to Quantitative Genetics. ${ }^{\text {nd }}$ Ed. English Language Book Society/ Longman. P. 288.

Hanson, C. H., H. F. Robinson and R. E. Comstock. 1956. Biometrical studies of yield in segregating population of Korean lespedeza. Agronomy Journal 48: 268-272.

Johnson, H. W., H. F. Robinson and R. E. Comstock. 1955. Estimation of genetic and environmental variability in soybean. Agronomy Journal. 47: 314-318.

Panse, V. G. 1957. Genetics of quantitative characters in relation to plant breeding. Indian J. Genet. 17:318-328. 
Rahman, M.M. 2009. Genetic variability and genotypes-environment interaction in wheat. M.S. Thesis, Bangabandhu Sheikh Mujibur Rahman Agricultural University, Gazipur.

Reynolds, M. P., S. Nagaranjan, M. A. Razzaque and O. A. A. Ageeb (eds.). 1997. Using canopy temperature depression to select for yield potential of wheat in heat- stressed environments. Wheat Special Report No. 42. Mexico. D. F.: CIMMYT.

Reynolds, M. P., M. Balota, M. I. B. Delgado, I. Amani and R. A. Fischer. 1994. Pyhsiological and morphological traits associated with spring wheat yield under hot, irrigated conditions. Aust. J. Plant Physiol. 21: 717-730.

Sharma, D. J., R. K. Yadav and P. K. Sharma. 1995. Genetic variability and association of some yield components in winter $\mathrm{x}$ spring nursery of wheat. Adv. in Pl. Sci. 8(1):95-99.

Shoran, J. 1995. Estimation of variability parameters and path coefficients for certain metric traits in winter wheat (Triticum. aestivum L.). Indian J. Genet. 55(4): 399405.

Singh, K. N., K. Neeraj, V. Kumar and S. Tim. 2006. Genetic variability of wheat (Triticum aestivum L.) lines for grain yield and component characters grown under sodic and waterlogged conditions. Indian Journal of Agricultural Science. 76(7): 414-419.

Vasil, I.K. and O.D. Anderson, (1997). Genetic engineering of wheat gluten (review). Trends in Plant Science, 2: 292-297.

Vilhelmsen, A.L., M.P. Reynolds, B. Skovmand, D. Mohan, K.N. Ruwali, S. Nagrajan and O. Stoelen. 2001. Genetic diversity and heritability of heat tolerance traits in wheat. Wheat Special Report. Mexico, D. F., CIMMYT. 